\title{
Synthesis and characterization of chitosan nanoparticles of
}

\section{Achillea millefolium L. and their activities [version 1; peer review: 2 approved with reservations]}

\author{
Dolly Kain, Suresh Kumar (iD
}

Medicinal Plant Research Laboratory, Department of Botany, Ramjas College, University of Delhi, Delhi, 110007, India

V1 First published: 04 Nov 2020, 9:1297

https://doi.org/10.12688/f1000research.26446.1

Latest published: 04 Nov 2020, 9:1297

https://doi.org/10.12688/f1000research.26446.1

\section{Abstract}

Background: Achillea millefolium L. is an herbal aromatic plant of family Asteraceae reported to have various medicinal activities in the literature. The current study evaluated the potential of chitosan nanoparticles of $A$. millefolium as an effective strategy for targeted treatment of bacterial diseases and urolithiasis.

Methods: A. millefolium was collected from Poonch, Jammu and Kashmir, and its inflorescence extracted in water by maceration. Chitosan nanoparticles of $A$. millefolium (AMCSNPs) were prepared by ionic gelation method using $0.1 \%$ chitosan, different concentrations of the cross-linking agent sodium tripolyphosphate (STPP; 0.5\%, 1\%, $1.5 \%, 2 \%)$ and different concentrations of $A$. millefolium extract $(0.5 \%$, $1 \%, 1.5 \%, 2 \%)$. Characterization of AMCSNPs was done using UV-Vis spectroscopy, Fourier transform-infrared (FT-IR) spectroscopy, dynamic light scattering (DLS) and transmission electron microscopy (TEM). Antibacterial screening of AMCSNPs was performed by welldiffusion method. Antiurolithiatic screening of AMCSNPs was done by nucleation and aggregation assay.

Results: The best chitosan nanoparticles of $A$. millefolium (AMCSNPs) were obtained with $0.1 \%$ chitosan, $1 \%$ STPP and $20 \%$ A. millefolium. These AMCSNPS showed maximum zone of inhibition of $30 \pm 0.5 \mathrm{~mm}$ using the well-diffusion method against both Bacillus subtilis (Grampositive) and Pseudomonas aeruginosa (Gram-negative) and maximum antiurolithiatic activity with $68 \%$ inhibition shown at aggregation stage.

Conclusions: The current study suggests that AMCSNPs are an excellent strategy for targeted drug delivery for treatment of bacterial diseases and urolithiasis.

Keywords

Achillea millefolium L., AMCSNPs, Drug delivery, Targeted treatment, Antibacterial, Antiurolithiatic

\section{Open Peer Review}

\begin{tabular}{ccc} 
Approval Status & $?$ \\
& 1 & 2 \\
\hdashline & $?$ & $?$ \\
version 1 & view & view
\end{tabular}

1. Alok Arun, Inter American University of Puerto Rico, Barranquitas, USA

\section{Dipjyoti Chakraborty, Banasthali Vidyapith,}

Banasthali, India

Any reports and responses or comments on the article can be found at the end of the article. 
This article is included in the Nanoscience \&

Nanotechnology gateway.

Corresponding author: Suresh Kumar (suresh.kumar@ramjas.du.ac.in)

Author roles: Kain D: Conceptualization, Formal Analysis, Investigation, Methodology, Writing - Original Draft Preparation, Writing Review \& Editing; Kumar S: Conceptualization, Formal Analysis, Resources, Supervision, Writing - Review \& Editing

Competing interests: No competing interests were disclosed.

Grant information: The University Grant Commission, University of Delhi provided financial support.

Copyright: @ 2020 Kain D and Kumar S. This is an open access article distributed under the terms of the Creative Commons Attribution License, which permits unrestricted use, distribution, and reproduction in any medium, provided the original work is properly cited.

How to cite this article: Kain D and Kumar S. Synthesis and characterization of chitosan nanoparticles of Achillea millefolium L. and their activities [version 1; peer review: 2 approved with reservations] F1000Research 2020, 9:1297

https://doi.org/10.12688/f1000research.26446.1

First published: 04 Nov 2020, 9:1297 https://doi.org/10.12688/f1000research.26446.1 


\section{Introduction}

Natural biopolymers are attractive products of living organisms as they serve a number of different applications for human health due to their biodegradability, such as vaccine delivery, drug development, and food preservatives ${ }^{1}$. Chitosan (CS) is a natural biopolymer and a derivative of chitin. It is obtained from different sources of chitin and differs on the basis of its degree of deacetylation ${ }^{2}$. In the last few years, CS nanoparticles (CSNPs) have drawn much attention due to their biodegradability, biocompatibility, quantum size effects, large surface to volume ratios, and their simple and inexpensive production ${ }^{3-5}$. Different biological activities of CSNPs have been reported, such as antimicrobial, antioxidant, anticancer ${ }^{6}$, drug delivery, tissue engineering, carbon nanotube, food preservative, and purification of water ${ }^{7}$. CSNPs successfully used in drug delivery for treatment of various diseases, including ocular drug delivery ${ }^{8}$, per-oral drug delivery ${ }^{9}$, nasal drug delivery ${ }^{10}$, pulmonary drug delivery ${ }^{11}$, mucosal drug delivery ${ }^{12}$, gene delivery ${ }^{13}$, buccal drug delivery ${ }^{14}$, vaccine delivery ${ }^{15}$, vaginal drug delivery ${ }^{16}$, and cancer therapy ${ }^{17}$ have been reported. Achillea millefolium is a perennial herbal aromatic plant belonging to the family Asteraceae with characteristically finely divided leaves and inflorescence in corymbose cluster. It has been reported to have different medicinal activities, including antibacterial and diuretic ${ }^{18,19}$. The current study was designed to evaluate the potential of CSNPs of A. millefolium (AMCSNPs) as an effective alternative of targeted drug delivery and treatment of various diseases, including bacterial infections specifically urolithiasis.

\section{Methods}

Collection, identification, and extraction of $A$. millefolium A. millefolium was collected from Pathanteer Village, Mendhar Tehsil, Poonch District(Jammu and Kashmir, India; GPS coordinates $33^{\circ} 39^{\prime} 40^{\prime}$ N- $74^{\circ} 11^{\prime} 11^{\prime \prime}$ E) and identified by Raw Materials Herbarium and Museum (RHMD), National Institute of Science Communication and Information Resources (NISCAIR), Pusa with reference IDNISCAIR/RHMD/consult/2018/329394. $5 \mathrm{~g}$ powder of inflorescence of A. millefolium was extracted in $50 \mathrm{ml}$ of water by maceration at $90^{\circ} \mathrm{C}$ using water bath.

Crude extract of the plant was evaporated using rotary evaporator (Khera KI- 102), which resulted in the semi solid form of extract. This was then weighed and dissolved in a known amount of solvent for making a stock concentration of the plant extract. Different concentrations were made by serial dilution.

\section{Bacterial strains and chemicals}

Strains of Bacillus subtilis (MTCC 441) and Pseudomonas aeruginosa (MTCC 1688) were procured from MTCC Chandigarh. All the chemicals used (chitosan, acetic acid, sodium tripolyphosphate (STPP), Tween-80, calcium chloride, sodium oxalate, tris buffer and $\mathrm{NaCl}$ ) were of good quality and purchased from Fisher Scientific International, Inc.

\section{Synthesis of chitosan nanoparticles of A. millefolium}

CSNPs were prepared by ionic gelation method. $10 \mathrm{ml} 0.1 \%$ chitosan solution was made in $1 \%$ acetic acid with different percentages of the cross-linking agent STPP $(0.5 \%, 1 \%, 1.5 \%$ and $2 \%$ ). $5 \mathrm{ml}$ of STPP was added drop wise to the chitosanacetic acid solution, which was magnetically stirred at room temperature. An opalescent color was observed, and stirring was continued for $60 \mathrm{~min}$.

To obtain AMCSNPs, variable concentrations of plant extract $(5 \%, 10 \%, 15 \%$ and $20 \%)$ were added to the $10 \mathrm{ml}$ chitosan solution by magnetic stirring prior to adding the $5 \mathrm{ml} \mathrm{STPP}$ drop wise. This solution was stirred for a further $2 \mathrm{~h}$ followed by centrifugation at $10000 \mathrm{~g}$ for $10 \mathrm{~min}$ and then the AMCSNPs were washed three times with distilled water. The $\mathrm{pH}$ of the nanoparticles was maintained at 4.8, and 1-2 drops of $1 \%$ Tween-80 was used to prevent agglomeration.

Percentage encapsulation efficiency of each concentration of extract was determined using the following formula ${ }^{20-22}$ :

Encapsulation efficiency $(\%)=$ (total amount - free amount/ total amount) $* 100$.

Characterization of chitosan nanoparticles of $A$. millefolium UV-Vis spectroscopy using SPUV-1000 spectrophotometer attached to Mwave professional software 2.0 (or any software used to obtain the UV- Vis absorption spectra) and spectrum between $200 \mathrm{~nm}-700 \mathrm{~nm}$ was obtained for determining the main absorbing region. FTIR (Fourier Transform-Infrared) Spectroscopy using spectrometer (Brukers) in the range of $1000 \mathrm{~cm}^{-1}-3500 \mathrm{~cm}^{-1}$ to identify the peaks of main functional groups, DLS (Dynamic Light Scattering) in the range between $0 \mathrm{~nm}$ to $1000 \mathrm{~nm}$ using zetasizer Nano ZS90 (Malvern Instruments Ltd., UK) at room temperature for particle size distribution and TEM (Transmission electron microscopy) at an accelerating voltage of $200 \mathrm{kV}$ using Tecnai G2 30U-twin kV Ultra-twin microscope to study the morphology.

\section{Antibacterial screening of chitosan nanoparticles of A. millefolium}

Primary culture of bacteria was obtained from lyophilized culture by inoculating in LB broth, which was incubated in an incubator shaker at $120 \mathrm{rpm}$ and $37^{\circ} \mathrm{C}$ for $12-16 \mathrm{~h}$. Pure colonies of each bacterium were obtained from primary culture by streak plate method using LB agar plates, which were inoculated in $\mathrm{LB}$ broth, incubated in an incubator shaker at $120 \mathrm{rpm} 37^{\circ} \mathrm{C}$ for 12-16 h. Absorption of bacterial culture was adjusted to $0.1 \pm 0.02$ at $600 \mathrm{~nm}$ using SP-UV1000 spectrophotometer to reach the concentration of $10^{8} \mathrm{CFU} / \mathrm{ml}$ for final use, which is equal to 0.5 McFarland standards, as previously performed in the literature ${ }^{23-25}$ to obtain a similar concentration of each bacterium. Each reading was taken thrice.

Antibacterial screening of AMCSNPs was done using welldiffusion method ${ }^{31}$. $1.5 \%$ LB agar plates were used and a $5 \mathrm{~mm}$ cork-borer made four wells in each plate. $20 \mu \mathrm{l}$ of $B$. subtilis and $P$. aeruginosa culture was added to the plates and spread using a glass spreader. $100 \mu \mathrm{l}$ of AMCSNPs was poured in the wells. Plates were sealed with parafilm, incubated at $28^{\circ} \mathrm{C}$ for $12-16 \mathrm{~h}$ and the zone of inhibition (ZOI) recorded. 
Antiurolithiatic screening of chitosan nanoparticles of A. millefolium

Nucleation and aggregation assays were used to determine the antiurolithiatic potential of AMCSNPs.

Nucleation assay: The method of Hennequin et al. ${ }^{27}$ was used with some minor modifications. Solutions of calcium chloride and sodium oxalate were prepared at a final concentration of $3 \mathrm{mmol} / \mathrm{l}$ and $0.5 \mathrm{mmol} / \mathrm{l}$, respectively, in a buffer containing Tris $0.05 \mathrm{~mol} / \mathrm{l}$ and $\mathrm{NaCl} 0.15 \mathrm{~mol} / \mathrm{l}$ at $\mathrm{pH} 5.5$. A total of $1.9 \mathrm{ml}$ of calcium chloride solution mixed with $200 \mu \mathrm{l}$ of AMCSNPs was incubated for 30 minutes in a $37^{\circ} \mathrm{C}$ water bath. Crystallization was started by adding $1.9 \mathrm{ml}$ of sodium oxalate solution. Equal volume of water has used for a control instead of AMCSNPs. The optical density of the solution was recorded at $620 \mathrm{~nm}$ for $420 \mathrm{sec}$ using spectrophotometer SPUV- 1000.

$\%$ Inhibition $=\{($ Abs. Control- Abs. Sample $) /$ Abs. Control $\} *$ 100

Aggregation assay: The method of Hess et al. ${ }^{28}$ was used with some minor modifications. 'Seed' $\mathrm{CaOx}$ monohydrate (COM) crystals were prepared by mixing calcium chloride and sodium oxalate at $50 \mathrm{mmol} / \mathrm{l}$. Both the solutions were equilibrated in a $60^{\circ} \mathrm{C}$ water bath for $1 \mathrm{~h}$ and then cooled at $37^{\circ} \mathrm{C}$ overnight. The crystals were harvested by centrifugation at $10000 \mathrm{~g}$ and then evaporated at $37^{\circ} \mathrm{C}$. COM crystals were used at a final concentration of $0.8 \mathrm{mg} / \mathrm{ml}$, buffered with Tris $0.05 \mathrm{~mol} / \mathrm{l}$ and $\mathrm{NaCl}$ $0.15 \mathrm{~mol} / \mathrm{l}$ at $\mathrm{pH} 5.7$. A total of $1 \mathrm{ml}$ of AMCSNPs were added in a test tube to $3 \mathrm{ml} \mathrm{COM}$ crystal solution and incubated at $37^{\circ} \mathrm{C}$. Equal volume of water was used for a control instead of AMCSNPs. Absorption at $620 \mathrm{~nm}$ was recorded at different time intervals ( $30 \mathrm{~min}, 60 \mathrm{~min}, 90 \mathrm{~min}$, and $120 \mathrm{~min}$ ).

$\%$ Inhibition $=\{($ Slope Control- Slope Sample $) /$ Slope Control $\}$ $* 100$

Statistical analysis

Statistical analysis was performed using Microsoft Excel 2007. One-way ANOVA was used followed by t-test to determine the significant difference of antibacterial activity between different samples and regression analysis was used to plot graphs of nucleation and aggregation assays.

\section{Results}

Synthesis of chitosan nanoparticles of A. millefolium

On addition of STPP to chitosan solution, an opalescent color was observed, which indicates the formation of CSNPs. Different concentrations of STPP $(0.5 \%, 1 \%, 1.5 \%$, and $2 \%)$ were used for nanoparticle preparation and $1.0 \%$ STPP was found to be most suitable with sharpest peak shown by UV spectroscopy, indicating the most CSNPs made (Figure 1). Therefore, $1.0 \%$ STPP was used to obtain AMCSNPs. Different percentages of A. millefolium water extract $(5 \%, 10 \%, 15 \%$ and $20 \%)$ in $0.1 \%$ of chitosan solution were used to make AMCSNPs and excellent loading efficiency was observed, i.e. $94 \%, 94.7 \%, 94.7 \%$, and $95.2 \%$ for $5 \%, 10 \%, 15 \%$ and $20 \%$ A. millefolium respectively. A standard graph for absorbance of A. millefolium extract at 417 $\mathrm{nm}$ (maximum absorption verses concentration of extract) was obtained. The amount of loaded extract was determined using the standard graph as a decrease in the absorption values of the supernatant of AMCSNPs indicated the loading of extract of the nanoparticles. Loading efficiency was calculated using the above encapsulation efficiency formula for each concentration. Hence 20\% AMCSNPs have been used for further analysis.

Characterization of chitosan nanoparticles of $A$. millefolium A broad absorption band between 200 to $300 \mathrm{~nm}$ was shown for the UV spectrum of AMCSNPs (Figure 2). FTIR spectra of CS showed peaks at $3324.15,2153.28,1638.72$ and 1279.29; FTIR spectra of CSNPs showed peaks at 3317.48, 2139.29 and 1638.46; and FTIR spectrum of AMCSNPs showed peaks at 3281.73, 2163.36 and 1636.78 (Figure 3). DLS revealed the size range of nanoparticles with $\mathrm{Z}$ average of $118 \mathrm{~nm}$ having characteristic peaks at $10 \mathrm{~nm}, 122 \mathrm{~nm}$ and $712 \mathrm{~nm}$, and highest intensity was recorded at size 10nm (Figure 4). TEM was used to study the morphology of the nanoparticles, which revealed a spherical shape with smooth surface. TEM also revealed the size of AMCSNPs: $<100 \mathrm{~nm}$ with smallest size of $4.15 \mathrm{~nm}$ (Figure 5).

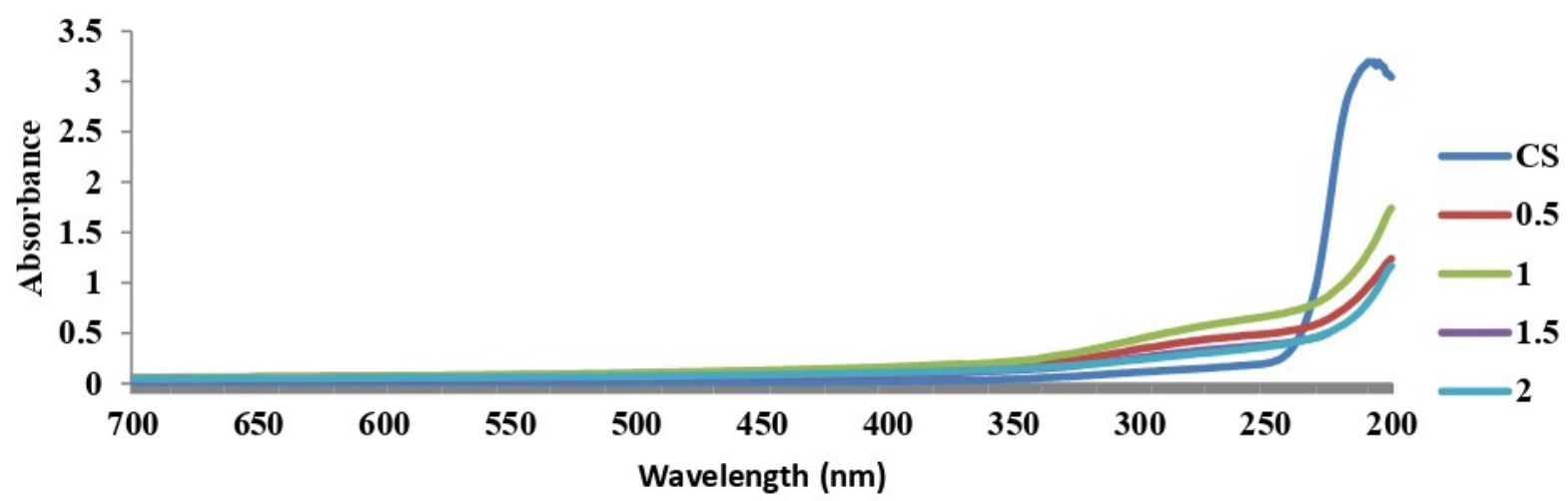

Figure 1. UV-Vis spectrum of chitosan (CS) and chitosan nanoparticles prepared with different concentrations of sodium tripolyphosphate $(0.5 \%, 1 \%, 1.5 \%$ and $2 \%)$. 


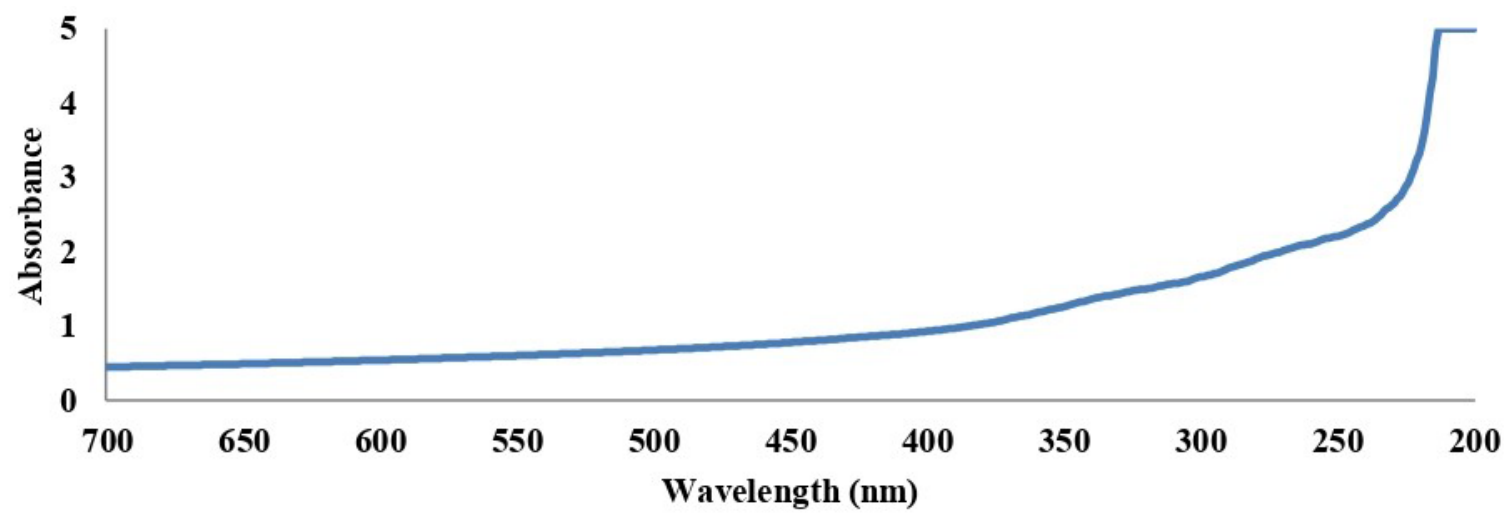

Figure 2. UV absorption spectrum of Achillea millefolium chitosan nanoparticles $(0.1 \%$ chitosan, $1 \%$ sodium tripolyphosphate and $20 \%$ A. millefolium).
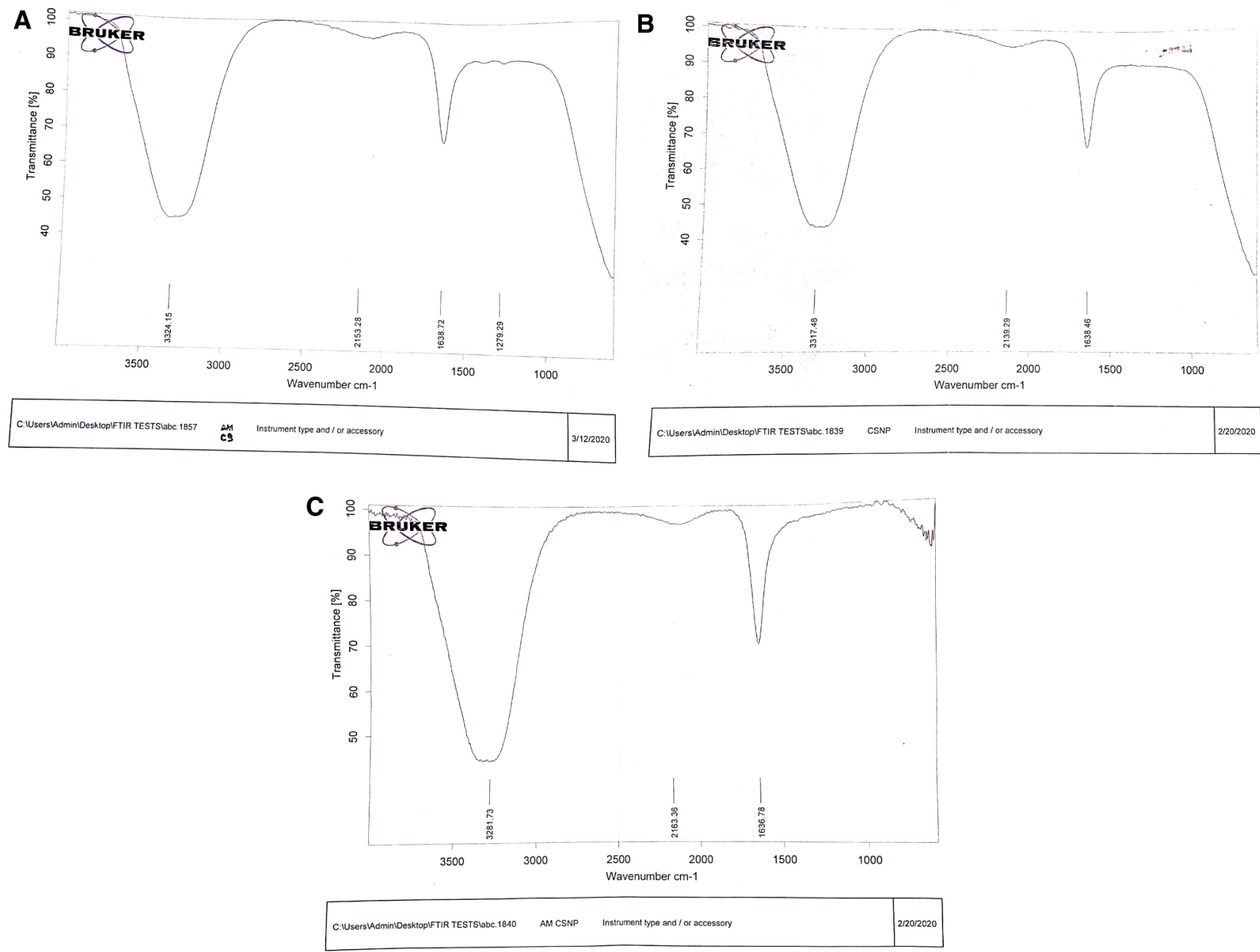

Figure 3. Fourier Transform-Infrared graph of chitosan (A), chitosan nanoparticles, (B) and Achillea millefolium chitosan nanoparticles (C). 


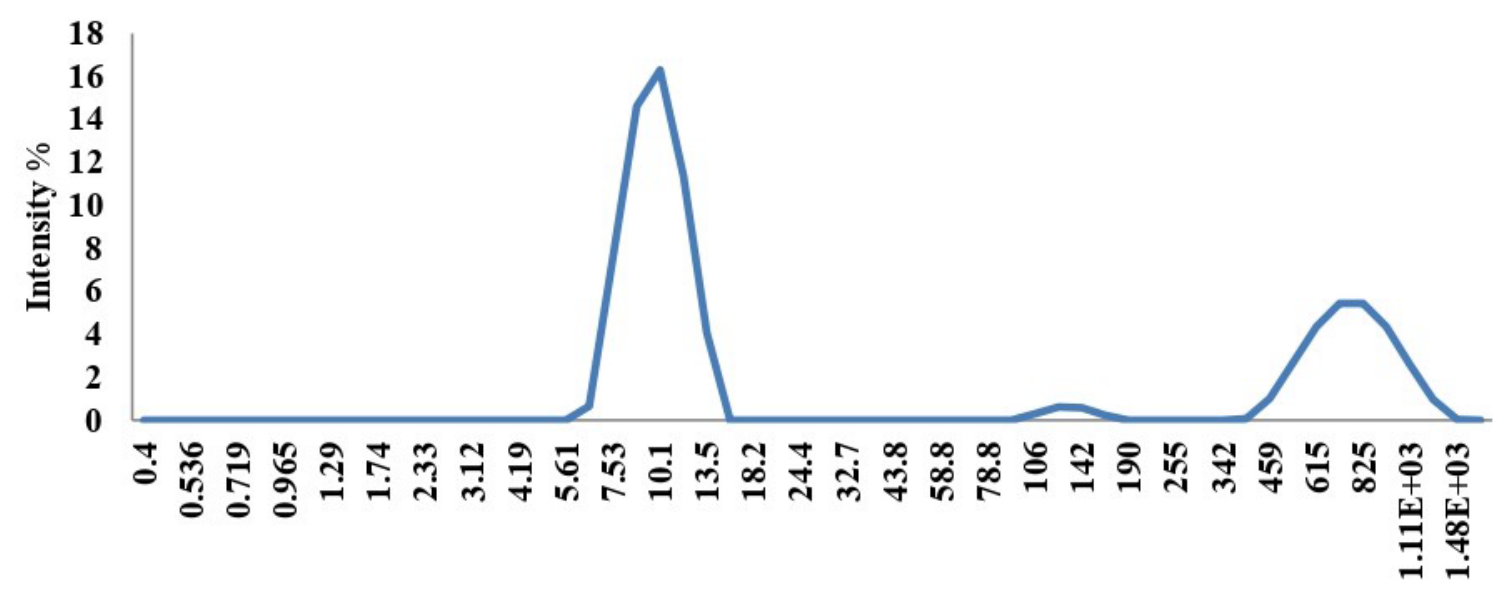

Size (nm)

Figure 4. Particle size distribution of Achillea millefolium chitosan nanoparticles, as revealed by Dynamic Light Scattering.

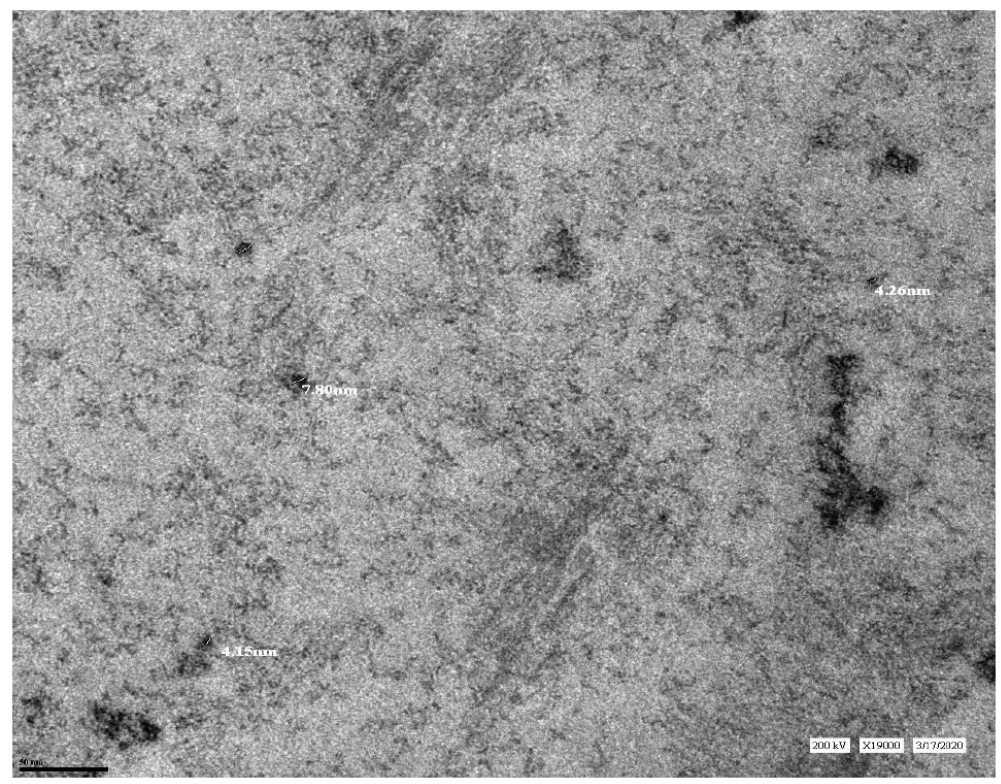

Figure 5. Transmission Electron Microscopy showing Achillea millefolium chitosan nanoparticles.

Antibacterial screening of chitosan nanoparticles of A. millefolium

AMCSNPs exhibited excellent antibacterial activity against both Gram-positive B. subtilis and Gram-negative P. aeruginosa. AMCSNPs showed three-times the increase in antibacterial activity as compared with A. millefolium extract only (control); ZOI increased from $10 \mathrm{~mm}$ to $30 \mathrm{~mm}$ against both $B$. subtilis and $P$. aeruginosa with a statistically significant difference between A. millefolium, CSNPs and AMCSNPs (Figure 6).

\section{Antiurolithiatic screening of chitosan nanoparticles of} A. millefolium

AMCSNPs showed significant antiurolithiatic activity with $68 \%$ inhibition in the aggregation assay and $51.26 \%$ inhibition in the nucleation assay as compared to $55.132 \%$ and $9.09 \%$ inhibition by A. millefolium extract (control). In the nucleation assay, the \% inhibition is nearly equal in the case of A. millefolium and AMCSNPs, but CSNPs did not show any inhibition. In the aggregation assay there is a significant increase in \% inhibition with 9.09\%, 63.63\% and 68\% inhibition by A. millefolium, CSNPs and AMCSPs, respectively, (Figure 7).

\section{Discussion}

For characterization of nanoparticles, different techniques used in the literature including UV- Vis spectroscopy, FTIR spectroscopy, DLS and $\mathrm{TEM}^{29,30}$. In our study, a UV-Vis absorption band for AMCSNPs of 200-300 nm indicates the presence of a CO group in the CSNPs, as reported by Vaezifer et al. ${ }^{31}$. A shift of 


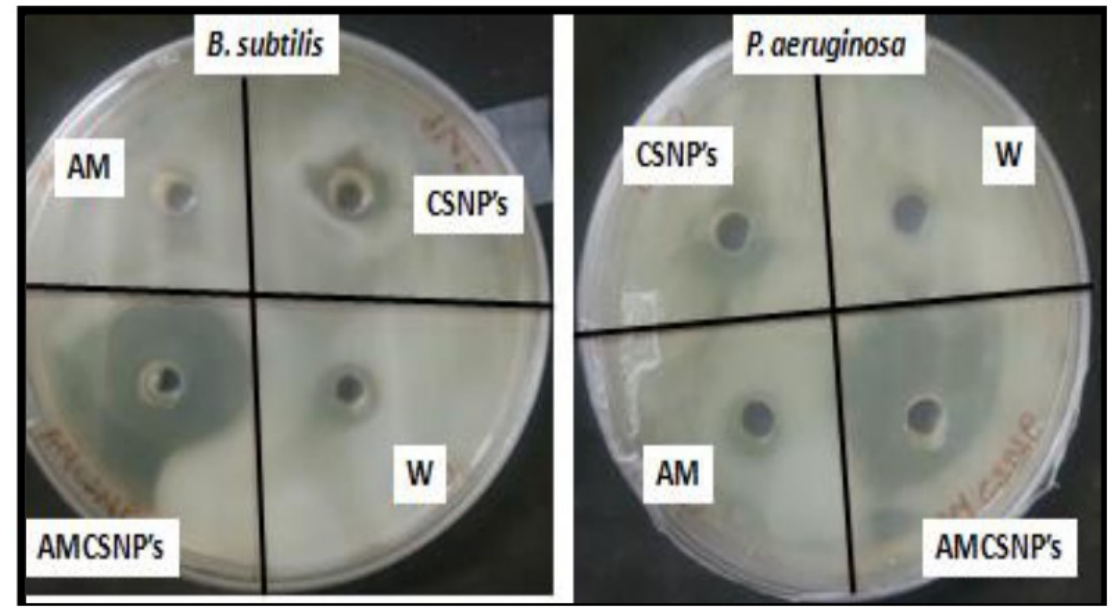

Figure 6. Antibacterial activity of Achillea millefolium chitosan nanoparticles. CSNP's= Chitosan nanoparticles, AM= A. millefolium and $\mathrm{W}=$ water.

\section{Nucleation Activity}

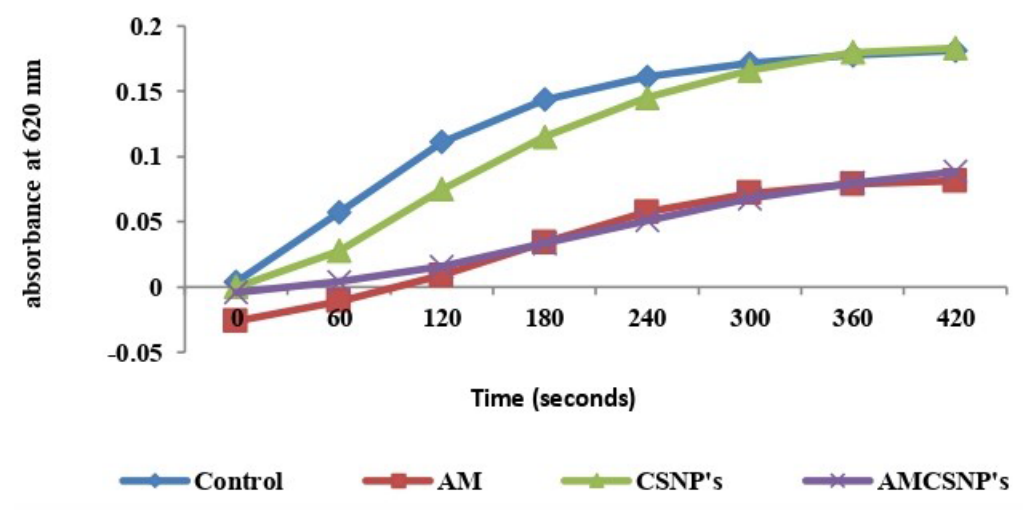

\section{Aggregation Activity}

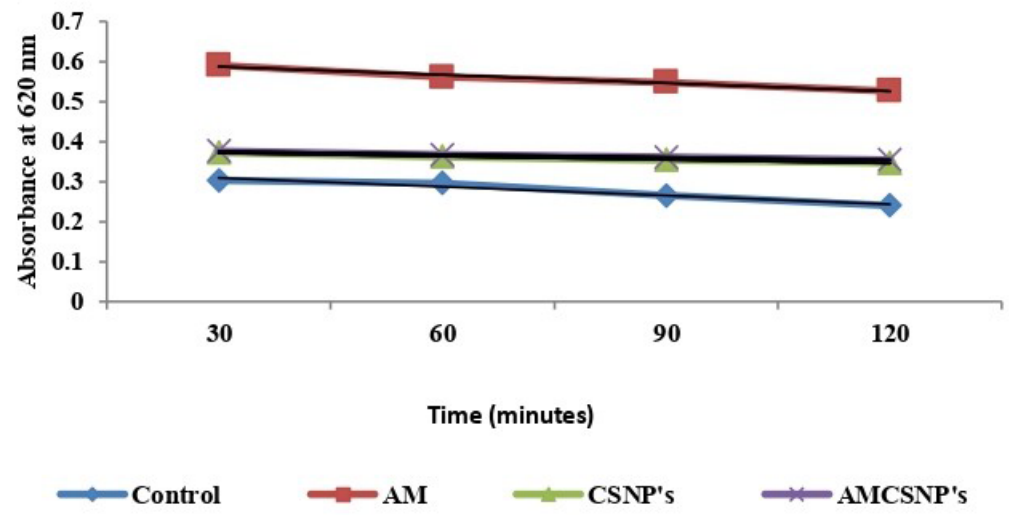

Figure 7. Antiurolithiatic activity of Achillea millefolium chitosan nanoparticles (AMCSNP's) as shown by a nucleation assay (A) and aggregation assay $(\mathbf{B})$. AM= A. millefolium, CSNP's= chitosan nanoparticles. 
FTIR peaks from $3317.48,2139.29$ and 1638.46 for CSNPs to $3281.73,2163.36$ and 1636.78 for AMCSNPs indicates that the loading of A. millefolium into the CSNPs, as reported by Khan et $a .^{32}$. Our DLS results are comparable to the average size of CSNPs reported in literature, i.e. 189 and $197 \mathrm{~nm}$ by Khan et al. $.^{32}, 216 \mathrm{~nm}$ by Agarwal et al. ${ }^{33}$, and size range of $135-729 \mathrm{~nm}$ by Rasaee et al. ${ }^{34}$ and $6.5-1331.2 \mathrm{~nm}$ by Iswanti et $a l .{ }^{35}$. TEM of AMCSNPs in our study revealed a spherical shape with a smooth surface, which was also reported by Da Silva et al. ${ }^{21}$.

Chitosan is a positively charged macromolecule, which interacts with the negatively charged microbial membrane, and results in the breakage of intracellular components. Chitosan acts as a chelating agent and limits toxin production and microbial growth $^{36-38}$. Antibacterial screening of Ocimum basilicum CSNPs against E. coli and Bacillus vallismortis have been reported by Rasaee et $a .^{34}$, chitosan-tripolyphosphate nanoparticles against Staphylococcus aureus and P. aeruginosa have been reported by Bangum et al. ${ }^{39}$, and against phytopathogens of tomato Xanthomonas and Erwinia strains by $\mathrm{Oh}$ et al. ${ }^{29}$. Gallic acid-chitosan conjugates have been reported to inhibit the formation of calcium oxalate crystals by Queiroz et al. ${ }^{40}$. Antiurolithiatic activity of Aerva lanata chitosan nanoparticles at $0.8 \mu \mathrm{g} / \mathrm{ml}$ concentration through nucleation assay have been reported by Chandirika et al. ${ }^{41}$ and Tridax procumbens by Chandirika et al. ${ }^{42}$. In our study, AMCSNPs showed excellent antibacterial activity against both B. subtilis and $P$. aeruginosa, and significant antiurolithiatic activity at aggregation stage of urolithiasis.

\section{Data availability}

Underlying data

Figshare: Chitosan nanoparticles of Achillea millefolium L., https://doi.org/10.6084/m9.figshare.12936293.v333.

This project contains the following underlying data:

- Output files of chitosan nanoparticles with different concentrations of STPP

- Raw data for Figures 1,2 and 4

- Unedited and uncropped FT-IR graphs and TEM images of AMCSNPs

- ZOI of antibacterial activity of AMCSNPs

- Absorption values of antiurolithiatic activity AMCSNPs

Data are available under the terms of the Creative Commons Zero "No rights reserved" data waiver (CC0 1.0 Public domain dedication).

\section{Acknowledgements}

The authors are thankful to the Principal, Dr. Manoj K. Khanna, Ramjas College, Prof. S.B. Babbar, Head, Prof. K.S. Rao, and Prof. Veena Agrawal, Department of Botany, University of Delhi, Delhi for providing necessary facilities and encouragement during the course of investigation.
1. Gomes LP, Paschoalin VMF, Del Aguila EM: Chitosan nanoparticles: production, physicochemical characteristics and nutraceutical applications. Rev Virtual Quim. 2017; 9(1): 387-409. Reference Source

2. Shukla SK, Mishra AK, Arotiba OA, et al.: Chitosan-based nanomaterials: a state-of-the-art review. Int J Biol Macromol. 2013; 59: 46-58. PubMed Abstract | Publisher Full Text

3. Ochekpe NA, Olorunfemi PO, Ngwuluka NC: Nanotechnology and drug delivery part 2: nanostructures for drug delivery. Tropical J Pharmaceut Res. 2009; 8: 275. Publisher Full Text

4. He X, Hwang HM: Nanotechnology in food science: Functionality applicability, and safety assessment. J Food Drug Anal. 2016; 24(4): 671-681. PubMed Abstract | Publisher Full Text

5. Naskar S, Koutsu K, Sharma S: Chitosan-based nanoparticles as drug delivery systems: a review on two decades of research. J Drug Targeting. 2018; 27(4): 379-393.

PubMed Abstract | Publisher Full Text

6. Kean T, Thanou M: Biodegradation, biodistribution and toxicity of chitosan. Adv Drug Deliv Rev. 2010; 62(1): 3-11. PubMed Abstract | Publisher Full Text

7. Gavhane $Y$, Gurav A, Yadav A: Chitosan and its applications: a review of literature. InterJ Biomed Pharm Sci. 2013; 4: 312.

8. Gupta $\mathrm{H}$, Velpandian $\mathrm{T}$, Jain $\mathrm{S}$ : Ion- and pH-activated novel in-situ gel system for sustained ocular drug delivery. J Drug Target. 2010; 18(7): 499-505. PubMed Abstract | Publisher Full Text

9. Gao P, Xia G, Bao Z, et al.: Chitosan based nanoparticles as protein carriers for efficient oral antigen delivery. Int J Biol Macromol. 2016; 91: 716-23. PubMed Abstract | Publisher Full Text
10. Shahnaz G, Vetter A, Barthelmes J, et al.: Thiolated chitosan nanoparticles for the nasal administration of leuprolide: bioavailability and pharmacokinetic characterization. Int J Pharm. 2012; 428(1-2): 164-70. PubMed Abstract | Publisher Full Text

11. Islam N, Ferro V: Recent advances in chitosan-based nanoparticulate pulmonary drug delivery. Nanoscale. 2016; 8(30): 14341-58. PubMed Abstract | Publisher Full Text

12. Martirosyan A, Olesen MJ, Howard KA: Chitosan-based nanoparticles for mucosal delivery of RNAi therapeutics. Adv Genet. 2014; 88: 325-52. PubMed Abstract | Publisher Full Text

13. Rudzinski WE, Palacios A, Ahmed A, et al: Targeted delivery of small interfering RNA to colon cancer cells using chitosan and PEGylated chitosan nanoparticles. Carbohydr Polym. 2016; 147: 323-32. PubMed Abstract | Publisher Full Text

14. Mazzarino L, Borsali R, Lemos-Senna E: Mucoadhesive films containing chitosan-coated nanoparticles: a new strategy for buccal curcumin release. J Pharm Sci. 2014; 103(11): 3764-71. PubMed Abstract | Publisher Full Text

15. Illum L, Jabbal-Gill I, Hinchcliffe $M$, et al.: Chitosan as a novel nasal delivery system for vaccines. Adv Drug Deliv Rev. 2001; 51(1-3): 81-96. PubMed Abstract | Publisher Full Text

16. Perinelli DR, Campana R, Skouras A, et al.: Chitosan Loaded into a Hydrogel Delivery System as a Strategy to Treat Vaginal Co-Infection. Pharmaceutics. 2018; 10(1): 23 .

PubMed Abstract | Publisher Full Text | Free Full Text

17. Lee SJ, Min HS, Ku SH, et al.: Tumor-targeting glycol chitosan nanoparticles as a platform delivery carrier in cancer diagnosis and therapy. Nanomedicine (Lond). 2014; 9(11): 1697-713. PubMed Abstract | Publisher Full Text 
18. Akram M: Minireview on Achillea millefolium Linn.J Membr Biol. 2013; 246(9): 661-663.

PubMed Abstract | Publisher Full Text

19. Lakshmi T, Geetha RV, Anitha R, et al.: Yarrow (Achillea millefolium Linn.) a herbal medicinal plant with broad therapeutic use - A Review. Int J Pharm Sci Rev Res. 2011; 9(2): 136-141.

Reference Source

20. Calvo P, Remunan-Lopez C, Vila-Jata JL, et al.: Chitosan and chitosan/ethylene oxide-propylene oxide block copolymer nanoparticles as novel carriers for proteins and vaccines.J Pharm Res. 1997; 14(10): 1431-1436. PubMed Abstract | Publisher Full Text

21. Da Silva SB, Amorim M, Pedro F, et al.: Natural extracts into chitosan nanocarriers for rosmarinic acid drug delivery. Pharm Biol. 2015; 53(5): 642-652.

PubMed Abstract | Publisher Full Text

22. Servat-Medina L, González-Gómez A, Reyes-Ortega F, et al.: Chitosantripolyphosphate nanoparticles as Arrabidaea chica standardized extract carrier: synthesis, characterization, biocompatibility, and antiulcerogenic activity. Int J Nanomed. 2015; 10: 3897-3909.

PubMed Abstract | Publisher Full Text | Free Full Text

23. Balouri, et al.: 2016 and Clinical and laboratory standard institute, USA.

24. Balouiri M, Sadiki M, Ibnsouda SK: Methods for in vitro evaluating antimicrobial activity: A review. J Pharm Anal. 2016; 6(2): 71-79. PubMed Abstract | Publisher Full Text | Free Full Text

25. LSI: Performance Standards for Antimicrobial Disk Susceptibility Tests,Approved Standard, 7th ed., CLSI document M02-A11. Clinical and LaboratoryStandards Institute, 950 West Valley Road, Suite 2500,Wayne, Pennsylvania19087,USA. 2012.

26. Balouiri M, Sadiki M, Ibnsouda SK: Methods for in vitro evaluating antimicrobial activity: A review. J Pharm Anal. 2016; 6(2): 71-79. PubMed Abstract | Publisher Full Text | Free Full Text

27. Hennequin C, Lalanne V, Daudon M, et al.: A new approach to studying inhibitors of calcium oxalate crystal growth. Urol Res. 1993; 21(2): 101-8. PubMed Abstract | Publisher Full Text

28. Hess B, Nakagawa Y, Coe FL: Inhibition of calcium oxalate monohydrate crystal aggregation by urine proteins. Am J Physiol. 1989; 257(1 Pt 2): 99-106. PubMed Abstract | Publisher Full Text

29. $\mathrm{OH}$ JW, Chun Se C, Chandrasekaran M: Preparation and In Vitro Characterization of Chitosan Nanoparticles and Their Broad- Spectrum Antifungal Action Compared to antibacterial activities against phytopathogens of tomato. Agronomy. 2019; 9(1): 21. Publisher Full Text

30. Arya A, Kumar S, Suryavanshi A, et al.: Biosynthesis of metallic nanoparticles from medicinal plants: A review. J Nanosci Technol. 2019; 5(5): 827-831. Publisher Full Text

31. Vaezifar S, Razavi S, Golozar MA, et al.: Effects of some parameters on particle size distribution of chitosan nanoparticles prepared by ionic gelation method. J Clust sci. 2013; 24: 891-903.

Publisher Full Text

32. Khan MA, Zafaryad M, Mehdi SH, et al.: Characterization and antiproliferative activity of curcumin loaded chitosan nanoparticles in cervical cancer. Int J Biol Macromol. 2016; 93(Pt A): 242-253.

PubMed Abstract | Publisher Full Text

33. Agarwal M, Agarwal MK, Shrivastav N, et al.: Preparation of chitosan nanoparticles and their in-vitro characterization. Int J Life Sci Scienti Res. 2018; 4(2): 1713-1720. Publisher Full Text

34. Rasaee I, Ghannadnia M, Honari H: Antibacterial properties of biologically formed chitosan nanoparticles using aqueous leaf extract of Ocimumbasilicum. Nanomed J. 2016; 3(4): 240-247. Reference Source

35. Iswanti FC, Nurulita I, Djauzi S, et al.: Preparation, characterization and evaluation of chitosan- based nanoparticles as CpG ODN carriers. Biotechnol Biotechnol Equip. 2019; 33(1): 390-396. Publisher Full Text

36. Leuba JL, Stossel P: Chitosan and other polyamines: Antifungal activity and interaction with biological membranes. In: chitin in nature and technolog. Muzzarelli R, Jeuniaux C, Gooday G,eds. Springer US. 1986; 215-222. Publisher Full Text

37. Jung BO, Kim $\mathrm{CH}$, Choi KS, et al.: Preparation of amphiphilic chitosan and their antimicrobial activities. J Applied Polym Sci. 1999; 72(13): 1713-1719. Publisher Full Text

38. Liu $\mathrm{H}$, Du $Y$, Wang $X$, et al.: Chitosan kills bacteria through cell membrane damage. Int J Food Microbiol. 2004; 95(2): 147-55. PubMed Abstract | Publisher Full Text

39. Bangum $\mathrm{H}$, Tandiono $\mathrm{S}$, Arianto $\mathrm{A}$ : Preparation and evaluation of chitosantriplophosphate nanoparticles suspension as an antibacterial agent. / App Pharm Sci. 2018; 8(12): 147-156. Publisher Full Text

40. Queiroz MF, Melo KRT, Sabry DA, et al.: Gallic Acid-Chitosan Conjugate Inhibits the Formation of Calcium Oxalate Crystals. Molecules. 2019; 24(11): 2074.

PubMed Abstract | Publisher Full Text | Free Full Text

41. Chandirika JU, Lakshmi PS, Mathiazhagan A, et al: Design and development of chitosan nanoparticles in target novel drug delivery systems for Urolithiasis. European J Biomed Pharm Sci. 2015; 2(4): 528-537. Reference Source

42. Chandirika JU, Sindhu R, Selvakumar S, et al: Herbal extract encapsulated in chitosan nanoparticles: a novel strategy for the treatment of Urolithiasis. Indo American J Pharm Sci. 2018; 5(3): 1955-1961. Publisher Full Text

43. Kain D, Kumar S: Chitosan nanoparticles of Achillea millefolium L. figshare Dataset. 2020.

http://www.doi.org/10.6084/m9.figshare.12936293.v3 


\section{Open Peer Review}

\section{Current Peer Review Status: ? ?}

\section{Version 1}

Reviewer Report 24 May 2021

https://doi.org/10.5256/f1000research.29196.r82696

(C) 2021 Chakraborty D. This is an open access peer review report distributed under the terms of the Creative Commons Attribution License, which permits unrestricted use, distribution, and reproduction in any medium, provided the original work is properly cited.

\section{Dipjyoti Chakraborty}

Department of Bioscience and Biotechnology, Banasthali Vidyapith, Banasthali, Rajasthan, India

The authors have used crude extracts of Achillea millefolium. The possible constituents of the inflorescence used especially with emphasis on secondary metabolites should be discussed with previous references.

Considering seasonal/low availability of flowers, how do the authors justify using inflorescence? Why not any other plant part?

Justify extraction in water at $90^{\circ} \mathrm{C}$, are there any previous reports? What was the duration of extraction?

Why were only Bacillus subtilis, and Pseudomonas aeruginosa used for the study?

The UV spectrum shows absorbance beyond 1 in the Y-axis (Figure-1). It is generally not recommended to have Abs above 1 as it gives erroneous results and the sample is suitably diluted. The authors may consider.

Since the spectrum shows very low or no absorbance other than the uv region, authors may provide another graph - maybe in the inset showing the spectrum only in the UV region for better signature spectrum.

Figure 2 should also be looked into on similar lines.

The authors have used the "well-diffusion method" for antibacterial screening and thus have not been able to calculate MIC. What was the concentration of extract used for the Zone inhibition study and whether a range of concentration was tried?

Discussion section needs a few lines on the possible constituents of $A$. millefolium extract and its implication on the formation of the nanoparticles and or the bioactivity. 
Is the work clearly and accurately presented and does it cite the current literature? Partly

Is the study design appropriate and is the work technically sound?

Yes

Are sufficient details of methods and analysis provided to allow replication by others? Yes

If applicable, is the statistical analysis and its interpretation appropriate? Yes

Are all the source data underlying the results available to ensure full reproducibility? Yes

Are the conclusions drawn adequately supported by the results?

Yes

Competing Interests: No competing interests were disclosed.

Reviewer Expertise: Stress Biology, Secondary Metabolite Biotechnology, Proteomics

I confirm that I have read this submission and believe that I have an appropriate level of expertise to confirm that it is of an acceptable scientific standard, however I have significant reservations, as outlined above.

Author Response 31 May 2021

Suresh Kumar, University of Delhi, Delhi, India

I am thankful to the reviewer for critical analysis of work. The point wise response is as follows:

1. Two reasons for use of Inflorescence, firstly its diuretic uses confirmed by the traditional healers of the collection site. Secondly, crude extract of inflorescence has shown maximum antiurolithiatic activity which was determined in my previous study.

2. The temperature of extraction was used as per literature which gives best result at 10 to $20^{\circ} \mathrm{C}$ than B.P. of solvent used). Duration of extraction was $48 \mathrm{hrs}$.

3. Both bacteria are reported as causal agent for several human diseases/ infections (urinary tract infections, soft tissue infections, bacteremia, gastrointestinal infections, respiratory system infections) and also it cover the two main categories of gram negative ( $P$. aeruginosa) and positive bacteria (B. subtilis).

4. The sharp peak at particular wavelength indicates the formation of nanoparticles; further dilution will not cover the entire spectrum and absorption pattern. 
5. The antibacterial activity of nanoparticles was determined prepared by $1 \mathrm{mg} / \mathrm{ml}$ extract and compared with the same crude extract to determine the enhancement in the activity.

6. GC-MS of crude extract of inflorescence of $A$. millefolium reveals the presence of different bioactive compounds including Lupeol, Stigmasterol, alpha.-amyrin, and gamma.-sitosterol.

Competing Interests: No competing interests were disclosed.

Reviewer Report 12 May 2021

\section{https://doi.org/10.5256/f1000research.29196.r83420}

(C) 2021 Arun A. This is an open access peer review report distributed under the terms of the Creative Commons Attribution License, which permits unrestricted use, distribution, and reproduction in any medium, provided the original work is properly cited.

\section{Alok Arun}

Institute of Sustainable Biotechnology, Department of Science and Technology, Inter American University of Puerto Rico, Barranquitas, Puerto Rico, 00794- 517, USA

The authors assessed the chitosan nanoparticles isolated from a herbal aromatic plant Achillea millefolium (here after referred as AMCSNPs) using ionic gelation method after applying various concentrations of plant extract. Further, the authors measured the antiurolithatic and antibacterial activity using two bacterial species and consequently propose AMCSNPs to be an alternative strategy for targeted delivery.

The research seems to be original and will definitely contribute to broadening the fundamental knowledge about AMCSNPs. However, the authors have potential to make this paper stronger by including few minor details/corrections:

1. Why was only inflorescence used for extract isolation? Providing an explanation can highlight the significant of tissue selection for chitosan nanoparticles isolation.

2. Besides herbarium, did others use any other method to ascertain the identity of plant species used in the study?

3. Authors mention the use of Hess et al., for performing the aggregation assay. There is a brief mention of minor modifications in the protocol. Can they highlight the specific modifications that was used in the protocol?

4. The TEM images are not very clear. Can the authors provide the magnification used for these images? 
5. The sentence in discussion, "A shift of FTIR peaks from 3317.48, 2139.29 and 1638.46 for CSNPs to $3281.73,2163.36$ and 1636.78 for AMCSNPs indicates that the loading of A. millefolium into the CSNPs, as reported by Khan et al." is not clear. Can authors rephrase the sentence and provide clarity?

6. The paper will greatly benefit from an image of the plant and the tissue that was used in the study.

7. The study design may have included one more tissue (for example leaf, stem etc) from the plant for comparative purposes.

Is the work clearly and accurately presented and does it cite the current literature? Yes

Is the study design appropriate and is the work technically sound?

Partly

Are sufficient details of methods and analysis provided to allow replication by others? Yes

If applicable, is the statistical analysis and its interpretation appropriate?

I cannot comment. A qualified statistician is required.

Are all the source data underlying the results available to ensure full reproducibility? Yes

Are the conclusions drawn adequately supported by the results?

Yes

Competing Interests: No competing interests were disclosed.

Reviewer Expertise: Plant Biotechnology, Genomics, Molecular Genetics, Bioinformatics

I confirm that I have read this submission and believe that I have an appropriate level of expertise to confirm that it is of an acceptable scientific standard, however I have significant reservations, as outlined above. 
The benefits of publishing with F1000Research:

- Your article is published within days, with no editorial bias

- You can publish traditional articles, null/negative results, case reports, data notes and more

- The peer review process is transparent and collaborative

- Your article is indexed in PubMed after passing peer review

- Dedicated customer support at every stage

For pre-submission enquiries, contact research@f1000.com 